\title{
The invention of trials in camera in security cases
}

\author{
A. W. Brian Simpson
}

Even in peacetime in Britain it is possible to be tried for very serious criminal offences in camera, in particular for offences against the Official Secrets Acts (hereafter OSA). The most remarkable trials in camera have been cases thought to involve national security. For example, in 1961 George Blake was convicted of five OSA offences and sentenced to forty-two years' imprisonment after proceedings largely conducted in secret, though the sentence itself was pronounced, as the law required, in open court. After Blake had been sentenced, and Prime Minister Harold Macmillan had made a brief statement, a question was asked by Arthur Holt MP. 'Is the Prime Minister aware that what is troubling many people is why, if the Russians know all about this person, security reasons prevent the House of Commons knowing more about him?' Macmillan replied, 'Anyone who has been engaged upon or has knowledge about these matters knows that is rather too simple a view. It was for that reason that the Lord Chief Justice decided to hold the trial in camera.' ${ }^{1}$ Blake decamped to Russia, but to this day nothing is available in the Public Records. ${ }^{2}$ In 1983 the so-called Cyprus Eight (or seven) were tried, largely in camera ${ }^{3}$ and acquitted, and during the twentieth century there were many other examples.

Originally the common law criminal trial on indictment was open. Thus Sir William Blackstone in the Commentaries does not even trouble to mention the fact that there were no secret trials on indictment - one does not state the obvious. The public and theatrical nature of the criminal trial is well illustrated by the great state trials: even trials of very important people by their peers were held in public. The trial of Queen Ann Boleyn is said to have been attended by over two thousand people. ${ }^{4}$ Indeed the people participated, albeit informally, in the trial. Thus when Thomas Howard, Duke of Norfolk, was convicted of high treason in 1571 the account published in the State Trials tells us that, 'Then the Lord Steward broke his rod and the people cried God Save the Queen.' The people might also express approval of an acquittal, as they did at the trial of Lord Dacre of the North in 1535, when there gave forth, 'The greatest 
shoute and crye of joy the like no man livying may remember that ever he heard.' 6

The public nature of the criminal trial persisted into the nineteenth century. When William Corder was convicted in 1828 for the murder in the Red Barn, not only were his trial and execution public, the dissection of his body took place in public in the shire hall and the mangled remains exhibited in the courtroom. Charles Cottu, a French judge, travelled the northern circuit in 1819. He was struck by the publicness of English trials. ${ }^{7}$ David Cairns comments: 'Publicness comprised two characteristics. Firstly access, which enabled spectators to see the law in action. The public's right of access was enhanced by conducting the trial as a single and fast event. ... The second feature of publicness is orality, by which the audience in court could follow every step of the trial. ${ }^{8}$ And by the 1830 s those who could not attend could read extended newspaper accounts of trials, defendants' last moments, and executions.

In the nineteenth century all this began to change. Punishment became progressively more secret within the new penitentiaries. Press attendance at executions finally passed out of use in the 1920s. In the end the Home Office succeeded in suppressing the publication of any information concerning executions or final hours, with the executioners bonded to reveal no details. Secret execution always had its critics, including Lord Wensleydale. He argued,

The fundamental principle which governs the administration of the criminal law in this country was that all proceedings involving life and liberty should be conducted in public, and it was only in accordance with it that the punishment should be carried out in public. By that means the public are certain that everything was done fair and right, and that justice had been done. ${ }^{9}$

But the critics lost.

The trial itself remained open. As late as 1905 the editors of Archbold's Pleading, simply do not mention that criminal courts do not sit behind closed doors. It had never occurred to anyone that they could. Secret trials were associated with evil institutions such as the Star Chamber, or the Spanish Inquisition. The 1910 edition of Archbold, however, strikes a different tone.

At common law a trial on indictment or criminal information must be held in a public court with open doors. . . . In dealing with certain classes of criminal trial the presiding judge not infrequently asks women and young persons to leave the court, and there is undoubted power to exclude or eject persons who disturb the proceedings. $^{10}$

Later editions vacillate on whether the judge could order the women and young persons out, or merely request them to leave.

Archbold mentions two statutes which gave express power to hold proceedings in camera, or exclude sections of the public: the Punishment of Incest Act 1908; and the Children Act $1908 .{ }^{11}$ Section five of the Punishment of Incest 
Act stated baldly that 'All proceedings under this Act are to be held in camera.' It was added as an amendment proposed by Lord Halsbury; he believed that press publicity would produce 'a crop of similar offences at other Assizes'. ${ }^{12}$ The provision was repealed in $1922 .{ }^{13}$ Thereafter the press in general apparently did not report cases of incest, or cloaked them in euphemism, and this too provoked judicial criticism. In $1925 \mathrm{Mr}$ Justice Roche lamented that 'there was a stratum of society who did not realize that incest was a crime'. He favoured calling a spade a spade. '[T] he Press would be rendering the best service to the community if it put down perfectly plainly that a prisoner was convicted of incest. ${ }^{14} \mathrm{Mr}$ Justice McCardie expressed the same view two years later at the Warwick Assizes. ${ }^{15}$ Whether the proletariat amended their ways one can but wonder. The Children Act provided for the exclusion of everyone except parties, lawyers and bona fide members of the press when a person under 16 was giving evidence of an indecent nature, and introduced a general exclusion of persons under 14 in such cases. ${ }^{16}$ The statutory powers were given 'in addition to, and without prejudice to any power which a court may possess to hear proceedings in camera'.

By 1900 it had become a little uncertain whether civil proceedings could be heard in camera with the consent of the parties. There were situations in which there was thought to be such a power, but it is not until 1913 that we get a leading case on the subject - Scott v. Scott. ${ }^{17}$ In Scott the House of Lords firmly laid down the general principle that courts were open, and judges had no general discretion to exclude the public even with the consent of the litigants. There were, however, some exceptions - cases involving wards of court and lunatics, and actions concerning the protection of trade secrets. Also individuals might be excluded to preserve order. Lords Haldane and Loreburn went a little further: other cases might arise when it was proper to exclude the public, so long as this was necessary to achieve the paramount aim of doing justice.

The enunciation of this vague principle opened the way to an extension of the world of the secret trial. There are two reported divorce cases soon after Scott v. Scott in which women were permitted to testify in private because the nature of the evidence might have inhibited them from testifying in public. In Cleland v. Cleland and McLeod (1913) $)^{18} \mathrm{Mr}$ Justice Bargrave Deane, no doubt from his employment something of a connoisseur, described the case as 'about as horrible a case as I ever came across', and in Moosbrugger v. Moosbrugger $(1913)^{19}$ both counsel and Mrs Moosbrugger, agreed that 'The whole case is so horrible.'

So far there has been no explicit mention of the possibility of holding criminal trials in camera, nor of national security, nor the need to control espionage, as a ground for doing so. Victorians did not bother too much about spies. ${ }^{20}$ Attitudes changed with the German spy scare of the early years of the twentieth century, and the establishment of the Secret Service Bureau in 1909; 'MI5', a name it has popularly retained. ${ }^{21}$ The first OSA of 1889 said nothing 
whatever about secret trials, and was indeed very little used. The first achievement of the Secret Service Bureau was to secure the passage of the OSA of $1911,{ }^{22}$ directed against espionage. It made, however, no provision for holding trials in camera. A number of supposed spies or agents were tried for OSA offences shortly before the First World War: Lieutenant Siegfried Helm (1910), Dr Max Schultz (1911), Heinrich Grosse (1912), Armgaard Graves (1912), George Parrott with Karl Hentschel (1913), Wilhelm Klauer (1913), and Frederick Schroeder (1914). ${ }^{23}$ All these trials were quite public. ${ }^{24}$

After some uncertainty the military persuaded the government to introduce what amounted to a form of martial law legitimised by emergency legislation under the Defence of the Realm Acts (hereafter DORA). The first DORA allowed regulations to be made 'for securing the public safety and the defence of the realm' and specifically:

(a) to prevent persons communicating with the enemy or obtaining information for that purpose or any purpose calculated to jeopardise the success of the operations of any of H.M. forces or to assist the enemy; or

(b) to secure the safety of means of communication or of railways, docks or harbours ... ${ }^{25}$

The original maximum penalty for DORA offences was penal servitude for life, but the third DORA of 27 November permitted, but did not require, the death sentence for offences committed with the intention of assisting the enemy. ${ }^{26}$ Under this and the consolidated regulations of 28 November $1914^{27}$ DORA offences became triable either by court martial, or summarily. DORA offences tried summarily could attract only six months' imprisonment.

So spies were normally charged with DORA offences carrying the death penalty, and not with OSA offences. ${ }^{28}$ During the war these regulations were continuously amended and made more stringent. The most extreme example, and one which is in such blatant conflict with the rule of law as to be barely credible, is Regulation 18A. ${ }^{29}$ This required anyone who had been in communication with a spy, or had attempted to communicate, to prove his innocence. He must show that he did not know the person was a spy, and had no reason to believe he was. A spy was very widely defined - it included someone convicted under Regulation 18, or reasonably suspected of having infringed it, with intent to assist, or anyone outside Britain who was suspected of being a receiver of information. Anyone who had the address of such a spy, or other information about him in his possession, was deemed to be in communication unless he could exonerate himself. In effect the regulation, tailored to fit the meagre evidence which MI5 could offer a court, normally derived from postal censorship, was designed to ensure that anyone the authorities suspected of being a spy was more or less bound to be convicted if put on trial. MI5 was unable to produce proof that suspected spy addresses abroad were spy addresses, so convictions for attempting to send letters to such addresses had to depend on suspicion alone. Nevertheless there were supposed spies who were interned 
because it was thought impossible to secure convictions; one can only assume that the evidence against such persons was very weak indeed. ${ }^{30}$ Some must have been wholly innocent. In some cases the problem was that the individual had done nothing which could, by any stretch of the imagination, rank as an offence. ${ }^{31}$

It might be thought that DORA or its regulations would have introduced trials in camera. But neither the original DORA of 8 August 1914 nor the second DORA of 28 August did so. ${ }^{32}$ The first espionage trial from which the public was excluded from part of the proceedings, and this in a capital case, was that of Carl Hans Lody, alias Charles Inglis, which took place on 30 and 31 October and 2 November 1914. He was shot in the Tower on 11 November. Lody was a naval reserve officer, who certainly had been openly active as a spy, and he did not really deny this at his trial, much of which was devoted to demonstrating what a noble fellow he was, and how decently the British had treated him. His trial was, legally, very curious. He was not charged either with OSA or DORA offences. Instead, by a decision of the Cabinet on 8 October, he was charged with commission of a war crime, specifically war treason. The theory was that engaging in espionage rendered him liable under the international law of war, after a trial, to the penalty of death, or some more lenient sentence. $^{33}$

Spies, unlike other combatants who had become prisoners, were traditionally liable to be executed. The 1894 edition of The Manual of Military Law states briefly that 'Spies, when taken, are punishable by death since, as Vattel observes, there is scarcely any other means of guarding against the mischief they do. ${ }^{34}$ From the citations it is clear that this refers only to persons operating in disguise, or under false pretences. The edition of February 1914 deals with the matter in a much more elaborate way. This rewriting was provoked by the Hague Rules of $1907,{ }^{35}$ whose definition of a spy reads: "A person can only be considered a spy when, acting clandestinely or on false pretences, he obtains or endeavours to obtain information in the zone of operations of a belligerent, with the intention of communicating it to the hostile party.' As the Manual points out, people acting openly outside the zone of operations (like Lody) were not covered. The Manual therefore recommends that such persons should be charged with war treason. 'Indeed in every case where it is doubtful whether the act consists of espionage, once the fact is established that an individual has furnished or attempted to furnish information to the enemy, no time need be wasted in examining whether the case corresponds exactly to the definition of espionage. ${ }^{, 36}$

The Manual then explains that espionage and war treason are types of the more general category of war crime, and gives a very wide definition of war treason, which includes 'obtaining, supplying and carrying of information to the enemy' or attempting to do so; war treason also covered such activities as sabotage, and aiding prisoners to escape ${ }^{37}$ Those accused were entitled, the Manual points out, to a trial, which would be by a military or civil court. They 
might be punished by death, or suffer a more lenient sentence, not including corporal punishment. The juridical basis was the law and usages of war.

The 1914 edition of the Manual was relied upon in Lody's case. The background to the Cabinet decision was very curious. In August 1914 an unnamed person, believed to be German, and equipped with a concealed radio transmitter was, so the War Office thought, captured by the police and lodged in Bodmin Prison. ${ }^{38}$ Lord Kitchener, the Secretary of State for War, consulted the Lord Chancellor, Lord Haldane, and ruled that the individual should be tried by court martial and, if guilty, hanged. Haldane set out his theory of the matter thus:

If an alien belligerent is caught in this country spying or otherwise waging war he can, in my opinion, be Court Martialled and executed. The mere fact that he is resident here and has what is popularly called a domicile is not enough.... When war breaks out an alien becomes prima facie an outlaw, . . . if he is a spy or takes up arms . . . and he becomes a person without legal rights. By international law he must have a trial before punishment but the trial may be by Court Martial. He cannot invoke the jurisdiction of the civil courts. ${ }^{39}$

The Adjutant General wondered whether Haldane really meant a military tribunal, not a court martial, and also wondered whether DORA had not limited the power of punishment to penal servitude for life. ${ }^{40}$ Haldane's theory makes no reference either to the prerogative or to the usages of war.

In reality there was no such person in Bodmin Prison. But the thinking inspired by this phantom, and by the Manual, led to the form of proceeding used for the unfortunate Lody. After a discussion in Cabinet the Army Council on 9 October instructed that Lody be tried under international law, and not under DORA, so as not to limit the penalty to penal servitude for life. The military tribunal, though not legally a general court martial, behaved exactly as if it was one. It was presided over by a retired Major General, Lord Cheylesmore, sitting with eight other officers; he would preside over all courts martial for spies held in Britain during the war.

There was no concealment of the name of the accused, nor the fact that he was on trial, and only part of the trial was held in camera. The request came from the prosecution, handled by Archibald H. Bodkin. ${ }^{41}$ The trial was very fully reported in The Times from 29 October to 11 November, when Lody was shot. Accounts of his execution read like stories from R. G. Henty's novels or the Boy's Own Paper. He wrote a letter of thanks to those arranging for his killing, shook hands with the Assistant Provost Marshal, Lord Athlumney, and he even arranged the romantic gesture of sending a ring to an unidentified lady in America. ${ }^{42}$ His native village planted a tree as a permanent memorial, and a destroyer named after him escorted the doomed battleship Bismarck at one point during her final voyage. ${ }^{43}$

Two questions arise out of Lody's trial. The first is whether his spying did constitute a war crime, war treason. The 1958 Manual of Military Law argues that the view that a spy commits a war crime is incompatible with Article 31 
of the Annex to the Hague Convention of 1907, which entitles a spy who rejoins his own side and is later captured to be protected as a prisoner of war. If spying was a war crime such a person could still be tried and punished. The Manual diffidently suggests that the idea that persons like Lody were guilty of war treason was doubtful, without mentioning his case. ${ }^{44}$ At the time the Adjutant General, as we have seen, had expressed doubts. It seems fairly plain that Lody's execution was unlawful both under domestic and international law. The second question is whether Lord Cheylesmore's action in clearing the court was lawful. There was certainly no statutory basis for it, but then there was no statutory basis for the trial anyway, and the theory under which Lody was tried was one that required a trial under international law, but whose form was unregulated. So if we assume that the trial was lawful then it was surely lawful to hold it partially or wholly in camera.

No later spy trials in the First World War in Britain followed the precedent of Lody's case; from late November 1914 it became possible to impose a death sentence under DORA. Abroad matters were different. The register of trials before military tribunals (not courts martial) between October 1916 and October 1917 records a number of trials of civilians for war treason. ${ }^{45}$

Under the DORA of 27 November $1914^{46}$ the military was given the power to try anyone, including civilian British subjects, by court martial for DORA offences, even offences involving a possible death penalty. Courts martial were regulated by the Army Act (1881) and procedural rules made under it. ${ }^{47}$ These allowed the President to clear the court, but only for deliberation among its members. A note added that a person who interfered with the proceedings might nevertheless be excluded, 'a power incident to every court as necessary for the proper conduct of the proceedings'. The Manual of Military Law of 1914 said that except for deliberation: 'the court must be open to the public, military or otherwise, so far as the room or tent in which the court is held can receive them. It is not usual to place any restriction on the admission of reporters for the press. ${ }^{48}$ So, unless courts martial possessed some inherent power to exclude the public in the interests of security, they could not sit in camera in spy trials or any other trials.

So far as I am aware the issue had never arisen before the First World War. No doubt it was easy enough to keep the public away from courts martial, if this was desired. There was, furthermore, no appeal from a decision by court martial, though its decision had to be confirmed. So if a court martial did decide to sit in camera the legality of this could not be raised by way of appeal. In theory it would be possible to apply to the civil courts for habeas corpus. Indeed Lody could have done this, though if he was simply an outlaw the civil court would not have heard his application. But neither he nor anyone else, so far as I know, had ever done this; the pioneer was, as we shall see, one Doyle in 1917.

The first supposed spy tried by court martial after the DORA of 27 November 1914 was a Swede, Rolf Jonsson, who was tried at Falmouth on 26 February 
1915, and acquitted. ${ }^{49}$ I have discovered nothing about him. The next was that of Robert Rosenthal, but his trial took place after an important change in the law in 1915, which I shall first describe. ${ }^{50}$ The fact that civilians could be tried for capital DORA offences by courts martial produced opposition, to which the government capitulated. So the DORA of 16 March 1915 allowed civilians to claim civil trial by judge and jury. ${ }^{51}$ This right could be withdrawn in the event of an invasion, or, by proclamation, for any 'other special military emergency arising out of the present war'. This restoration of the right to jury trial in 1915 had been strongly opposed by the War Office. The Adjutant General argued that courts martial were better able to judge the gravity of offences from a military point of view, provided speedier trials, a more effective deterrent, and were not hampered by technicalities of procedure and rights of appeal. Sentences were, however, subject to executive review. In Ireland only trial by court martial provided any hope of securing a conviction. But the War Office view did not prevail. The War Office rejected a compromise, which would have been to either drop the death penalty for DORA offences, or introduce an appeal is such cases. ${ }^{52}$

It was this DORA which provided the first statutory warrant for holding a common law criminal trial which might lead to the death penalty in camera. Section 1 (3) provided:

In addition to and without prejudice to any powers which a court may possess to order the exclusion of the public from any proceedings . . . if . . . application is made by the prosecution, in the interests of national safety, that all or any portion of the public should be excluded during any part of the hearing, the court may make an order to that effect, but the passing of the sentence shall in any case take place in public.

This was made part of the bill by a Lords amendment.

Somewhat surprisingly the Act made no provision for holding courts martial, as distinct from regular civil courts, in camera. I have found no material explaining this; it is unlikely to have been an oversight. Possibly the reason was that in practice Lord Cheylesmore could be relied upon to clear the court if deemed necessary, and any challenge would be technically difficult. Given wartime conditions, and the attitude of the judiciary, a challenge through habeas corpus would be unlikely to succeed. Had the provision allowing trials in camera been applied to courts martial there would also have been a difficulty over announcing the sentence in open court. For the military practice was to promulgate sentences of death in private, once confirmed. At the conclusion of a court martial on a capital charge the convicted person knew of the conviction, but was not then told whether he was to be killed or not. ${ }^{53}$ Most capital sentences were not confirmed. ${ }^{54}$

After the change in the law a considerable number of espionage or similar cases arose, and arrangements had to be made to settle which would go to the civil courts, and which to courts martial. In June 1915 the Director of Public 
Prosecutions, Sir Charles Mathews, obtained a ruling from the Attorney General, Sir John Simon, approved by the Secretary of State for War, Lord Kitchener, 'that trials of all persons accused of espionage (except British subjects) should be by Court Martial; cases of alleged spies for whom there is a reasonable ground for believing they are of American nationality to be reported to DPP for special consideration by the AG ${ }^{55}$ In the whole course of the war there were twenty-six courts martial of supposed spies under DORA in Britain, and one trial, Lody's, under international law. ${ }^{56}$ Fourteen death sentences were imposed, four being commuted to penal servitude for life. ${ }^{57}$ Nine persons were shot in the Tower, ${ }^{58}$ and one hanged in Wandsworth Prison. ${ }^{59}$ There were two ten-year, three five-year, and one three-year sentences of penal servitude; one two-year, one eighteen-month and one twentyeight-day sentences of imprisonment with hard labour; one twenty-eight-day and one seven-day term of imprisonment; and two acquittals. ${ }^{60}$

The first spy trial for a DORA offence to take place civilly after the Act of 1915 was never completed; it was that of Anton Kupferle, and it was partly heard in camera. ${ }^{61}$ He had been arrested on 19 February, and caught through the postal censorship. He claimed to be a US citizen. The case predates the ruling by the Attorney General, but the Army Council, no doubt because of Kupferle's citizenship claim, instructed that he should not be tried by court martial. The trial opened at the Old Bailey on 19 May. To enhance the jollity of the proceedings the practice of carrying bouquets of flowers was revived. After some evidence had been given the Attorney General applied for the trial to continue in camera; the defence did not object. The accused gave evidence and was cross-examined, but the evidence presented in camera and the hearing were not reported. Kupferle committed suicide during the trial, on 20 May, The Times publishing his suicide note, written on a slate. This was the first civil trial for espionage conducted almost wholly in camera. But the fact that the trial was taking place, the name of the accused, and details about his death, were all made public, as was much of the evidence.

The first civil spy trial conducted entirely in camera was that of Karl Friedrich Muller, tried with Peter Hahn in June 1915. ${ }^{62}$ They were tried jointly, and since Peter Hahn was a British subject, though of German extraction, they were not tried by court martial. The Grand Jury was charged in camera on 20 April. At the request of the prosecution the entire trial was held in camera, though the court was opened before sentence. Muller was sentenced to death and Hahn to seven years' penal servitude. Muller appealed, and the appeal was also held in camera, though a reporter from The Times was allowed to attend. The appeal was dismissed on 22 June. ${ }^{63}$ Muller engaged in the normal courtesies, shaking hands with the firing squad which then shot him. This was on 23 June. Although the trial had been in camera the fact that Muller and Hahn were to be tried, the trial itself, the sentence, the appeal, and the execution were all reported in the press at the time. 
The first spy trial by court martial after the legal change in 1915 was that of Robert Rosenthal, who was German. ${ }^{64}$ On 6 July 1915 The Times announced in advance that the entire trial would be held in camera, so there had been an executive rather than a judicial decision on this matter. The general court martial opened on 11 July. The fact that Rosenthal's trial was to take place was not concealed; a large crowd gathered outside the Westminster Guildhall, but members of the public were excluded by armed soldiers. Rosenthal, who had made two suicide attempts, was hanged in Wandsworth on 15 July, and not shot. In 1932 MI5 tried to discover the reason for this. ${ }^{65}$ The files did not provide any explanation, but the officer who looked into the matter had heard at the time "that the Court considered a bullet too good for him on account of his extremely cowardly behaviour during the trial'. Being shot, rather than hanged, was considered to be an honourable way to die. An alternative explanation offered by S. T. Felstead was that some unspecified administrative problem in the Tower, where executions were carried out in the miniature rifle range, lay behind the decision. ${ }^{66}$ Rosenthal's execution was reported in the press.

In the world of the secret state matters always seem to get worse, and the cases of Haicke Marinus Petrus Janssen, and Wilhelm Johannes Roos, in July 1915, introduced a more extreme form of secrecy. ${ }^{67}$ They were among seven agents arrested in May and mid-June 1915. ${ }^{68}$ They were tried by general court martial on 16 and 17 July 1915 for the DORA offence of espionage against Regulations 18 and 48. Both were convicted, sentenced to death, and, after confirmation, shot in the Tower on 30 July 1915. Roos earned some praise for having asked and received permission to finish his cigarette. The public was allowed to know little about this at the time. On 15 July The Times announced, without giving any names, 'The authorities announce the arrest of two alleged spies. Their trial will take place by general Court Martial to-morrow [16 July] at the Middlesex Guildhall. The whole proceedings will be in camera. They will be charged with collecting and attempting to collect for communication to the enemy information about his Majesty's Fleet.' Then, on 31 July, 'It is officially announced that the two persons who were charged with espionage and found guilty by General Court Martial at the Westminster Guildhall on July 16 and 17 were found guilty and sentenced to death. The sentence was duly confirmed and was carried out yesterday morning.' So it had come about that persons could both be tried in secret and then executed, with only the barest public revelation of what they were supposed to have done, or even who they were.

There were, after this, some cases where there was no secrecy. ${ }^{69}$ But from July 1915 the authorities surrounded most espionage trials with enhanced secrecy. Thus on 11 September 1915 the following appeared in The Times after the event, that is to say, too late for any person outside the secret state to influence the outcome: 
Unnamed Spy Executed.

Tried by Court Martial.

It is officially announced that a person who was charged with espionage and tried by General Court Martial on August 20 and 21 was found guilty and sentenced to death. The sentence was duly confirmed and carried out yesterday morning.

This laconic announcement refers, as we now know, to one Ernst Waldemar Melin. A Swede, Melin had been tried by general court martial on 20 August, sentenced to death, and shot in the Tower on 10 September after, somewhat like Muller, shaking hands with his guard, a variant form of socially acceptable behaviour. He died, it was said, like the gentleman he had once been. ${ }^{70}$

A similar announcement was made on 18 September about 'Another Unnamed Spy', in fact Augusto Alfredo Roggen or Roggin, a Uruguayan, tried with Melin, and shot on 17 September. ${ }^{71}$ And on 20 October the Secretary of the War Office announced that two prisoners, tried by general court martial on 28, 29, and 30 September had been convicted, and one sentenced to death, the other to five years' penal servitude. The execution had taken place on 19 October, so this announcement too came after the event. The executed man was Fernando Buschman, a Brazilian. ${ }^{72}$ Thomson waxes eloquent over his noble bearing. He played his violin until a late hour the night before his execution, finally kissing the instrument and saying, 'Goodbye, I shall not want you any more.' As if this were not enough he refused to have his eyes bandaged, 'facing the rifles with a courageous smile'. ${ }^{73}$ The individual sentenced to five years' penal servitude was Josef Marks, who was eventually repatriated to Germany after the war, probably in October $1920 .^{74}$

Why did the authorities arrange to try spies in camera? Most spies were caught through postal censorship; trials in camera concealed the details. MI5 knew that certain addresses were used by spies, who employed either secret ink, or codes. ${ }^{75}$ Thus Buschman was caught because he communicated with two addresses in Rotterdam which featured in other spy cases. MI5 may have sent false information to the Germans purporting to emanate from a spy who had in reality been caught and shot, an anticipation of the double agent system operated in the Second World War. Secret trials would be essential to this. According to Thomson this was done in Muller's case, and payment was indeed received for the information; Felstead has the same story. ${ }^{76}$ This seems very implausible in Muller's case. Although his trial was held in camera his arrest, trial, and execution were openly announced in The Times. ${ }^{77}$

The enhanced level of secrecy soon spread to civil trials. Thus, when George Breeckhow (alias George Parker, alias Reginald Rowland) was tried with Lizzie Wertheim in September 1915 before Justices Bray, Sankey, and Low, the prosecution applied for the whole case to be heard in camera. Mr Justice Bray asked, 'Are there any objections? [there were none] Then let it be so.' The 
judges were told that secrecy was 'necessary in the interests of the national safety' and simply accepted this. Indeed I know of no case in which an application by the Crown for a trial in camera has ever been rejected, though there may have been such cases. On 26 September The Times reported the fact of the trial and the sentences - death for Breeckhow and ten years for Wertheim but gave no names. There was an unsuccessful appeal on 18 October to the full Court of Criminal Appeal. This too was heard entirely in camera. Breeckhow was shot on 27 October; The Times announced next day that an unnamed spy had been executed. He had claimed US citizenship, probably falsely. Wertheim, who had acquired British citizenship through marriage to a naturalised German, died in Aylesbury prison in 1920.

So the position had now been reached when not only aliens, but even British citizens, could be tried and sentenced for offences involving the risk of a death penalty behind a veil of almost complete secrecy, for this was no isolated case. Courtenay (or Kurt) Henslop de Rysbach, a British subject by birth though of Austrian extraction, was tried civilly in camera, and, the jury having disagreed, was retried in October $1915 .{ }^{78} \mathrm{He}$ was sentenced to penal servitude for life, and Thomson records that 'His name was not made public at the time; only the fact that a British subject had been found guilty of espionage was disclosed, and the papers began to wonder why a British spy had been so leniently treated.' Felstead confirms this, and quotes a leader from the Westminster Gazette expressing mild surprise at the sentence. ${ }^{79}$

Those who did not have British citizenship could hardly expect to be treated better. A curious example is provided in Eva de Bournonville. She was described by Thomson as 'probably the most incompetent woman spy ever recruited by the Germans', and in her prison file as refined, of superior education, a brilliant linguist, and very neurotic. ${ }^{80}$ She was a mercenary spy, caught through postal censorship, sending low-grade information on the result of a Zeppelin raid of Croydon. Although she was not a British citizen she was tried civilly in January 1916 before Justices Darling, Scrutton, and Rowlatt. A civil trial was favoured by the Attorney General and Home Secretary, though opposed by Bodkin. The context was the Edith Cavell affair, which produced enthusiasm for demonstrating that the British, unlike their opponents, knew how to treat women decently. ${ }^{81}$ Bournonville was sentenced to death, and this was upheld by a full Court of Criminal Appeal, but following Cavell's execution her sentence was commuted to penal servitude for life. Had she been male she would certainly have been executed. The Times announced the charge, trial, failure of her appeal and outcome, but not her name. ${ }^{82}$ This information came from some official, but one file ${ }^{83}$ indicates that it was not until 20 July 1916 that the security service itself, through its chief of counter-espionage, Major R. J. Drake, issued a press notice which was cleared with Matthews, the Director of Public Prosecutions. This merely said: "The letter "M" was attached to a woman of Danish origin, Swedish by naturalization, who was sentenced to death in January, 1916, by a Civil Court, the sentence being confirmed on appeal, but 
subsequently commuted to penal servitude for life.' In 1920 she was still in prison, and on 17 July 1920 Mr Justice Darling wrote to the Home Office urging clemency. MI5 recommended that she should serve ten years in prison, which would have led to her release in 1926 at the age of around $51 .{ }^{84}$ But as a result of an initiative taken by Winston Churchill she was released on licence in 1922 and deported to Sweden.

The legality of trials in camera on security grounds in cases not covered by the DORA of 1915 came before the civil courts in two reported cases, an action of detinue in 1916, and a challenge to a court martial by habeas corpus proceedings in the following year. The story behind Norman v. Matthew and Another (1916) ${ }^{85}$ was a curious one. A magistrate, in connection with a prosecution under DORA Regulation 27 (prohibition against alarming reports etc.), had made an order under Regulation $51 \mathrm{~A}^{86}$ which authorised the police to raid premises occupied by the Independent Labour Party. They seized documents aimed at discouraging recruiting. The magistrate heard the case in camera and made a destruction order. An unsuccessful attempt was made to quash the order by certiorari as being ultra vires. The Divisional Court upheld holding the proceedings, which were said not to constitute a trial at all, in camera, and this in a case which had nothing whatever to do with espionage. ${ }^{87}$ Some of the documents belonged to C. H. Norman of the City of London branch of the ILP, who was the founder of the Stop the War Committee; they were thought to have been retained by the authorities, in particular by the Director of Public Prosecutions and the Metropolitan Police Commissioner. So he sued them in the Westminster County Court. The suit was dismissed as frivolous and vexatious, and here too the proceedings were in camera. The Divisional Court (Justices Lush and Sankey) affirmed that the County Court had an inherent power to proceed in camera, and was correct in doing so under the principles laid down in Scott v. Scott. According to Mr Justice Lush, if there are materials before the Court for concluding that it is necessary in order to secure that justice is done, the proceedings should be in camera' ${ }^{88} \mathrm{Mr}$ Justice Sankey put it rather differently, thinking the case came within one of the exceptions mentioned in Scott v. Scott - here 'secrecy is of the essence of the cause'. ${ }^{89}$ Both judges thought the power should be exercised with caution, but Sankey revealed that the practice of holding proceedings in camera was by this time becoming common. '[N]umerous other cases have been before the Courts recently where a similar course has been taken. ${ }^{, 90}$ The Court of Appeal refused leave to appeal. The disease was clearly spreading.

The legality of holding courts martial in camera first came before the civil courts in R. v. Governor of Lewes Prison ex parte Doyle, ${ }^{11}$ arising out of the Irish Easter Rising. Gerald Doyle had been tried in camera by field general court martial on 5 May 1916, and had been transferred to England to serve his sentence of three years' penal servitude. He made an application for habeas corpus, one ground being 'The conviction was bad because the field general court martial heard the case in camera.' The Attorney General warned that 'If 
this contention prevailed the consequences would be very serious; at the trial of a spy, for instance, where the most secret matters were in question, it would be impossible to exclude the public.' He further argued that the requirement, under the applicable rules of procedure, that the proceedings should be held in open court only meant that the accused, his legal representative, and anyone officially entitled to be there, should be admitted. This rubbish was too much for the court, but it nevertheless ruled that the trial had not been invalid. General Maxwell had put in an affidavit that there was unrest and fighting in Dublin at the time, and the court accepted that there had been a need to exclude the public. There was no affidavit from the president of the court martial. The Lord Chief Justice justified the decision by Scott v. Scott trial in camera was necessary in the interests of justice: 'In the existing local circumstances it was necessary to the public safety and the defence of the realm that neither the public nor the press should be admitted to the trial. It must be assumed that the members of the Court-martial took the same view.' This suggested that the judges would always allow a court martial to sit in camera if some sort of military necessity was asserted by the general officer commanding.

This is the only reported decision on the legality of secret trials by court martial; it was not an espionage case. The seventh edition of the Manual of Military Law, in reliance on it, states: 'A court-martial is an open court like other courts of justice, but it has inherent powers to sit in camera if such course is necessary for the administration of justice. ${ }^{92}$ Spies could surely expect no more sympathy from the judiciary than the rebellious Irish. ${ }^{93}$

All this was in wartime. But once security services obtain powers in wartime, they are reluctant to give them up in peacetime. Thus MI5 argued the powers it had acquired, including the power to try espionage cases in camera, needed to be retained. The underlying rationale was the Red Menace. Before the armistice of 1918 the War Office Emergency Legislation Committee, in its first interim report of 4 April 1918, had pointed out that during the war the Directorate of Special Intelligence ${ }^{94}$ had dealt with espionage cases under DORA regulations, to the practical exclusion of the OSA. There would be serious inconvenience if DORA came to an end and the only weapon was the OSA. ${ }^{95}$ It proposed a peacetime National Security Act. The plan was to repeal the OSA of 1911 and incorporate its provisions in the new act, which would also widen the range of offences by incorporating a number of DORA and other offences. MI5 particularly wanted to be able to obtain convictions without having to prove their case in court, as they had been able to do during the war. In the name of national security the rule of law was to be abandoned.

This produced an appalling clause 2, based on Regulation 18A of DORA, which made it an offence to be found in the United Kingdom having communicated or attempted to communicate with a foreign agent or someone reasonably suspected of being a foreign agent, unless the accused could prove that he did not know and had no reasonable grounds for supposing the person to 
be an agent. The National Security Bill also included provisions allowing cases to be heard in camera, though it retained the requirement that the sentence to be pronounced in public.

At a meeting in March 1919 the Home Office, in the person of Sir Edward Troup, the Permanent Under Secretary, with Sir Frederick Liddell, the Chief Parliamentary draughtsman, strongly resisted the proposed clause 2. What shocked them was the reversal of the burden of proof. A letter by C. D. Carew Robinson, expressing Troup's view, said the clause 'goes far beyond anything for which there is a justification in peace time in making an innocent person guilty of an offence unless he can prove his innocence'. Liddell described MI5's view that the offence was committed by simply coming to the United Kingdom as 'too fantastic to hold in a court of law'. So Walter Moresby, MI5's legal officer, went gloomily away to water down the definition of the new offence. But the Home Office, a department deeply committed to secret government, did not object to the provision for trials in camera.

The interdepartmental committee finished its work in March 1919. Sir Vernon Kell, the Director of MI5, was anxious that in some form Regulation 18A should be kept in being after peace officially dawned, as it did on 31 August 1921. 'It is vital to the national interest that the Regulation should be continued until it becomes, as may be expected, part of our permanent legislation. ${ }^{96}$ For a while nothing was done. In late 1918 an interdepartmental committee had indeed been set up under Sir Reginald Brade, Secretary to the War Office, to consider which DORA regulations and orders might be revoked or cancelled without harm to the national interest; it made recommendations which were accepted by a committee of the War Cabinet under Lord Cave, which thought other regulations might need to be revoked if the armistice held. ${ }^{97}$ However by 1920 little had been done to implement the policy of getting rid of unnecessary DORA regulations.

The imminence of the official ending of the war provoked action at last. On 20 October 1918 the Home Affairs Committee had rejected the idea of a National Security Act, fearing political opposition. It recommended simply amending the OSA, "confining such amendments to the most important changes it was desired to make'. ${ }^{98}$ An interdepartmental committee was set up to thrash out the details. The consequence was the OSA of 1920, which implemented so much of MI5's scheme as had survived Troup and Liddell. ${ }^{99}$ Section 2 of the new OSA was the watered-down version of the old DORA Regulation 18A; whereas $18 \mathrm{~A}$ had made the fact of communication with a reputed spy an offence unless the accused provided his innocence, the OSA version treated communication as merely evidence that an offence might have been committed. Section 8(4) made permanent the provision in the DORA of 1915 on trials in camera, now applied to OSA offences, 'on the ground that the publication of any evidence to be given or any statement to be made in the course of the proceedings would be prejudicial to the national safety . . . but the passing of sentence shall in any case take place in public.' So, in a form which could 
have been much worse but for the opposition of the Home Office, MI5 succeeded in carrying into peacetime, for the first time, statutory authorization for the holding trials in camera for offences involving security. ${ }^{100}$

By now, however, the courts had allowed the OSA to be used in cases which had nothing whatever to do with espionage or national security, thereby indirectly permitting trials in camera in cases which had no connection with espionage. The first example seems to be the case of Emile Jules Depuis in March 1915. He made use of information obtained as a postal censor for a form of blackmail. ${ }^{101}$ In 1926 Major F. W. H. Blake was prosecuted under the OSA for revealing to the Evening News a confession by the convicted murderer Frederick Bywaters. Blake was a retired prison governor, and this was the first use of the OSA against a fairly senior official. ${ }^{102}$ D. Hooper states that in 1919 a War Office clerk, Albert Crisp, and Arthur Homewood, company secretary of a tailoring firm, were prosecuted, Crisp having passed on information about clothing contracts. ${ }^{103}$

In the period between the wars there were a number of trials under the OSA which took place partially in camera - for example that of Dr Herman Goertz in March of $1936 ;^{104}$ that of Walter John Butterfield in September of the same year; ${ }^{105}$ and that of Percy Glading, Charles Munday, George Whomack, and Albert Williams in the Woolwich Arsenal case in $1938 .{ }^{106}$ In at least one case the defence objected, but without success. ${ }^{107}$ There seems to have been no public complaint. Two trials by court martial did, however, give rise to official anxiety, and led to proposals for general legislation on trials in camera.

One involved an aircraftman, John Donelly. He was convicted by a court martial held in camera for stealing confidential manuals and blueprints in 1928. ${ }^{108}$ He was thought to be connected with the IRA, and MI5 was involved. An application was made to the Judge Advocate General, Sir Felix Cassels, for a transcript. The trial had taken place under the Air Force Act of 1917, whose section 124 was based on section 124 of the Army Act of 1881, which long predated the invention of trials in camera. Under this a person convicted by court martial was explicitly given a right to obtain, on payment, a copy of the proceedings, including the transcript of the hearing. Was Sir Felix legally entitled to refuse to supply a transcript, or to edit it, or to supply it on conditions, where the trial had been held in camera? Of course Donelly had been at the trial, and he or his lawyer might have made notes. But a transcript might include details otherwise forgotten, and there was no way of telling what use might be made of it. Sir Felix had edited out names in transcripts provided to Irish prisoners tried under the Restoration of Order in Ireland Act 1920. In the Donelly case he allowed counsel to inspect the transcript, but he did not supply a copy. The same solution had been adopted by the director of public prosecutions in the case of Wilfred R. F. McCartney, who had been tried civilly in camera for OSA offences in January 1928, where the problem arose under section 16(1) of the Criminal Appeal Act of $1907 .{ }^{109}$ Sir Felix and the Treasury Solicitor considered seeking the law officers' opinion, but decided ignorance 
was bliss. '[I]t might be embarrassing to obtain too clear-cut a reply from the Law Officers, and that it was wise to leave the legal position a little vague, and, therefore, more open to the interpretation which the public interest demanded.' Sir Felix was prepared in any case in which defence interests might be affected to find ways and means of dealing with a demand for a transcript of secret evidence. Sir John Salmond, recently appointed to the Air Council as Air Member for Personnel, was also of opinion that a reference to the law officers was 'a gamble which it would be unwise to take'. ${ }^{110}$ Thus did officialdom reconcile itself to blatant law breaking in the public interest.

In March 1933 the issue arose again. Norman Baillie-Stewart, a lieutenant in the Seaforth Highlanders, was tried by general court martial for a number of OSA offences. ${ }^{111}$ The names of some witnesses were suppressed, and part of the hearing was in camera. Baillie-Stewart was convicted, cashiered, and sentenced to four years' imprisonment. The Judge Advocate General, Sir Henry F. MacGeagh, anticipated being asked for a copy of the proceedings, which, on release from prison, Baillie-Stewart would sell to the press. It was felt that the issue could no longer be ducked. The law officers, Sir Thomas W. Inskip, and Sir Donald B. Somervell, gave it as their opinion that such a request could not lawfully be refused. ${ }^{112}$

This opinion produced consternation in the War Office. It was feared that Baillie-Stewart might try to compel the release of a transcript by bringing mandamus proceedings. At a meeting on 11 March 1935, at which neither the Home Office nor Scottish Office were represented, the favoured solution was a new OSA, covering both military and civil trials, which would allow the Secretary of State, "if satisfied that it is expedient in the interests of national safety' to withhold all or part of the transcript of proceedings heard in camera. A bill was drafted, and the Lord Chancellor said he was happy, so long as there was a right to inspect a transcript. But although discussions continued into 1936 the plan was, by 24 July, dead. The Home Office, in the person of Sir Alexander Maxwell, strongly opposed the idea as involving 'a grave departure from the accepted principles of justice'. ${ }^{113}$ The Scottish Office called it 'an unwarranted interference with the Courts of Justice'. ${ }^{114}$ The law officers emphatically agreed. ${ }^{115}$ On 4 March 1937 the Army Council formally dropped the idea. The Judge Advocate General made it clear that he would in future observe the law, and provide copies of proceedings. With an air of menace he said that if the Secretary of State directed him not to do so, and legal proceedings were brought to compel him to provide copies, a rule nisi being granted, 'the Attorney General will have the situation clearly before his mind when he appears on the hearing of the rule'. But Baillie-Stewart never did demand a copy of the proceedings, nor, so far as I know, did anyone else. And so the matter rested until the passing of the Army Act of 1955, which made explicit provision for the problem. ${ }^{116}$

Legal preparations for the Second World War started back in the 1920s, ${ }^{117}$ and when war eventually came an elaborate scheme of Defence Regulations 
(hereafter DRS), authorised by a parent Emergency Powers (Defence) Act, came into force. Under this new version of DORA the power to hold legal proceedings in camera was hugely extended. ${ }^{118}$ Any legal proceedings whatsoever, whether commenced before or after the Act, could be heard in camera, and the court could prohibit or restrict the disclosure of information about the proceedings if 'satisfied that it is expedient in the interests of the public safety or the defence of the realm'.

During the First World War the normal practice had been, as we have seen, to try alien spies by court martial under DORA. The legal arrangements in the Second World War were rather different. The DRS did not provide for courts martial, which Maxwell of the Home Office strongly opposed. ${ }^{119}$ Nor did the regulations permit the death penalty. ${ }^{120}$ It was assumed that spies and serious saboteurs would be charged with treason. Hence when the war began there was no specific special provision for the trial and execution of spies and saboteurs.

Doubts soon arose as to whether a recently landed enemy agent would be amenable to the law of treason, which applies only to those who owe allegiance. Resident enemy agents would owe allegiance, but it was hard to see how an agent who arrived by parachute in order to blow up some installation, or whatever, could sensibly be treated as owing allegiance upon touching down. The whole question came before the Home Policy Committee of the War Cabinet in 1939. ${ }^{121}$ At a meeting in the War Office on 1 December, MI5, represented by Sir Eric B. Holt Wilson and Brigadier O. A. Harker, favoured trial of all supposed spies by courts martial. The War Office accepted this, and did not want the army to be left merely with the disagreeable disposal task of shooting spies convicted by civil courts. Maxwell was informed, and on 6 December he objected, pointing out that trial of British subjects by courts martial would be unacceptable politically, and arguing that it would be impossible to treat aliens differently - for example an American who had lived in Britain for ten or twenty years. The War Office continued to press for trial of aliens by courts martial though it did not think that the Lody precedent for military trial for a war crime would be likely to be followed. ${ }^{122}$

It was decided to deal with the whole question by drafting a bill which would permit the death penalty for acts done with intent to assist the enemy. The mode of trial remained controversial until a compromise was reached at a conference on 22 February 1940 - enemy aliens were to be tried by courts martial, but only if the Attorney General gave his consent. ${ }^{123}$ The bill became the Treachery Act of 1940. In the event only one spy was tried by the military during the war, Josef Jakobs, alias Joseph Rymer. He arrived by parachute on 29 January 1941 and was arrested near Ramsey in Huntingdonshire on 1 February, having broken his ankle on landing. He was tried in camera on 4 August 1941, and shot in the Tower on the fourteenth. His name does not feature in the Foreign Office list of 1945 nor in the reply, based upon it, of 'Spies Convicted under the Treachery Act by Civil Courts During the War' ${ }^{124}$ 
However, the account given by Lt Col. R. W. G. Stephens states that he was tried under the Treachery Act and this is correct. ${ }^{125}$ Quite why he was tried by court martial is unexplained; perhaps the reason was that he had been arrested by the military, and was thus in their custody.

A story, which has no satisfactory archival basis, has been told that two SS parachutists were dropped in Britain near Luton Hoo on 28 May 1941 to assassinate Rudolf Hess, who had arrived in Scotland on 10 May on his strange peace mission. ${ }^{126}$ Quite how they were to achieve this feat is wholly obscure. They were, it is said, captured and summarily executed - conceivably after some form of trial. ${ }^{127}$ It is possible that the two parachutists, if they ever existed, were killed in an attempted arrest by trigger-happy soldiers, or members of the Home Guard. The 1958 edition of The Manual of Military Law states that 'In the Second World War most spies were tried under the now spent Treachery Act 1940 on the direction of the Attorney General. ${ }^{128}$ The odd thing about this passage is the hint that there might have been more than one exception, but the reference could be to a trial abroad. It could also refer to the double cross system, under which some spies were never tried at all. Its meaning is obscure.

All documented trials for spying and similar offences in Britain during the war, apart from Jakobs's, were conducted before civil courts, and a considerable number of these trials took place entirely in camera. The most remarkable example is that of Captain John Herbert King. ${ }^{129}$ King had served in the First World War in the Artists Rifles, and, according to his own account, suffered a severe mental illness in 1917 - presumably shell shock. From August 1920 he was employed by the Foreign Office as a cypher officer. This was not a pensionable job, and cypher officers, whose work was extremely boring and poorly paid, were treated no doubt as somewhat lowly creatures, about on a par with a footman, by the socially elevated diplomats. In 1933 or 1934, according to his confession, he met Henry Pieck, a Dutchman and, it is said, an artist, at the International Club in Geneva. The man who introduced them was Raymond C. Oake, another cypher officer. Oake was then courting the stepdaughter of Captain C. F. B. Harvey, who was Passport Control Officer at Geneva. ${ }^{130}$ This was an intelligence job, and Harvey would have been connected with the Foreign Office intelligence service. Pieck was a friend of Harvey, and he knew others in the Foreign Office: J. P. Russell, R. Kinnaird, Captain H. B. W. Maling, and H. C. F. Tubb. ${ }^{131}$ Pieck claimed that money could be made on the stock exchange by advance knowledge of political developments, and King gave as this as the reason why he handed over material. He gave, for example, reports of conversations between Hitler and Sir Neville Henderson, and claimed that none was of any importance. In 1933 King met one Helen Wilkie, said to have been American, and started an affair. In 1936 Pieck left London, and King's contact then became a Hungarian, Petersen, who pressed him to provide the cypher itself. ${ }^{132}$ He strongly denied handing it over. King was paid substantial sums, $£ 50-£ 200$ a time by Pieck and $£ 100-£ 150$ a time by Petersen. In all he earned, so he claimed, $£ 2,500$. 
King was discovered through information provided by Walter Krivitsky, who defected to the US. After having claimed that the money received from Pieck and Petersen constituted gambling winnings King confessed on 28 September, apparently in order to exonerate Helen Wilkie; charges against her were dropped. In his diary Alexander Cadogan refers to the use of the third degree, and another story, leaked from MI5, is that King was filled with drink at the Bunch of Grapes public house in Curzon Street until he mournfully broke down. ${ }^{133}$ Although others were suspected, only Oake was actually dismissed, on 1 January 1940. Other cypher officers, who may well have been exonerated, were moved to other employment. After a committal for trial in camera on 10 October at Bow Street King was tried in camera at the Central Criminal Court on 17 October for OSA offences, to which he presumably pleaded guilty; he was sentenced to ten years imprisonment. The fact that a trial had taken place at all was kept entirely secret; Allason notes that no press announcement was made at the time. Information leaked out in 1956, when the Foreign Office issued a statement on the case. ${ }^{134}$ Whether the judge simply broke the law by not pronouncing sentence in open court, or whether some sort of fictitious observance of the law took place, arrangements having been made to ensure that nobody knew what was going on, is not known. He could have passed sentence in public and still made an order that no reporting take place. No other wartime trial, so far as I know, was entirely concealed. Little short of incredible though it may seem, the position had now been reached that a British citizen could be sent to prison for ten years (or for that matter I suppose for some longer period) in conditions of complete secrecy, the public being unaware that any trial had taken place at all.

Numerous other trials were conducted in camera. One group involved prosecutions of spies, or associates of spies, on capital charges under the Treachery Act. With the exception of Jakobs all such persons were tried civilly, and a list in the Foreign Office papers, which does not include Jakobs, gives the names of thirteen persons so tried and sentenced to death. Three were British (George Armstrong, Jose Estella Key and Oswald John Job). ${ }^{135}$ By the time the Parliamentary question for which the list had been prepared was answered three more names had been added, one being that of the Britishborn Duncan A. C. Scott-Ford. ${ }^{136}$ So the total number sentenced to death, if we include Jakobs, comes to seventeen. One of these persons, Menezes, was reprieved, and the other sixteen executed. One person, tried on a capital charge under the Treachery Act, Sjoern Pons, was acquitted, and then interned under Regulation 18B. Christobel Nicholson was also interned after acquittal in a trial conducted in camera, but it is probable that she was charged with a non-capital offence under the OSA. ${ }^{137}$ Though not viewed as a spy or agent but as a saboteur, Dorothy P. O'Grady was also tried in camera under the Treachery Act and sentenced to death, though her sentence was reduced to fourteen years' imprisonment on appeal. ${ }^{138}$ Capital charges, presumably under the Treachery Act, were also preferred against Nora C. L. Briscoe and Gertrude 
B. Hiscox, but withdrawn in a trial conducted in camera on 16 June $1941 .^{139}$ Most of those liable to the death penalty had done no harm whatever; the function of liability was to coerce agents into providing information or joining the double cross system.

None of these trials, however, was concealed. Whether the legal requirement that the sentence be pronounced in open court was actually observed in a realistic sense seems doubtful. Although the evidence is uncertain, what may have happened is that the court was ritually opened but, since members of the public and reporters had no idea that this was going to happen, none attended. The practice of the Ministry of Home Security and Home Office was, in collaboration with MI5, to issue a press statement immediately after spies had been executed, and the Home Office had been informed that they were dead. ${ }^{140}$ Why this extraordinary practice was adopted, no announcement having been made either before trial or after conviction and before execution, it is impossible to say; no documentation exists. Thus in the case of Josef Waldberg and Karl Meier a press release was issued at 9.25 am on 10 December 1940 stating their names, dates of birth and citizenship, a brief account of their capture, their conviction under the Treachery Act on 22 November, and their execution at Pentonville. This was accompanied by a 'Notes to Editors' stating 'Editors are asked not to press for additional facts or to institute enquiries. Editorial comment might profitably take the form of drawing public attention to loose talk of all kinds, particularly in the presence of strangers.'

That same evening a talk was given by someone from military intelligence on the $\mathrm{BBC}$; this gave further information and followed the same line. There were similar releases in the cases of Charles A. van den Kieboom ${ }^{141}$ and George Johnson Armstrong. In the case of Karl Theo Drueke and Norman Heinrich Waelti, executed on 6 August 1941, MI5 seems to have tried to seize the initiative by presenting a draft to the Home Office; in any event it was MI5 which had the whole story. But in accordance with a procedure which had been settled on 31 July the Home Office press officer prepared a draft, which was then vetted by Frank Newsam for the Home Office, and by MI5. The press was given quite a good story to print, and a communication from the Chief Press Officer of the Ministry of Information told editors to treat the release as 'the sole source of information on the subject. Any further details would be liable to involve breaches of security and will not be passed by the censorship.'

Trouble with the press broke out over the case of Jakobs. The War Office issued a brief statement on 15 August 1941 which was ill received in Fleet Street. The censor intended that nothing further be published, but both the Star and the Evening Standard ${ }^{142}$ investigated the matter and published fuller accounts of his capture; that in the Star was passed by a censorship accident. The outcome of this affair was a meeting of the Home Defence (Security) Executive on 28 August.

The problem, as the Chairman, Lord Swinton, saw it, was to release sufficient information to dissuade the press from pursuing further enquiries, whilst 
allowing the Security Service to decide what might not be told. The solution adopted was for MI5 to produce a full statement of the case from which the Home Office or War Office press officer and an MI5 officer would draft an appropriate statement. This would then be released and the press told that this was all the information they could use. Editors who stepped out of line would be prosecuted. MI5 strongly opposed allowing the press officer access to the transcript of the trial; however, the other members of the Home Defence Executive felt that MI5 had no grasp of what would generate a good story and keep the press happy.

The new procedure was first followed in the case of Karel Richard Richter, executed on 10 December 1941 after a violent struggle with the executioner. ${ }^{143}$ There was a formal press release setting out his name, citizenship, place of birth, trial, and appeal, noting they had been held in camera. This was followed by unofficial notes giving an account of his capture and providing material for a story. Francis Williams for the Ministry of Information added a memorandum telling editors that they must make no further enquiries, and threatening a total information blackout that if any editor misbehaved. So far as the press were concerned the new system provoked virtually no further trouble; the authorities presented it as a sort of bargain with the press.

Unhappily, however, it enraged such judges as had been involved in trials in camera. Having acceded to prosecution requests to try spies in camera, and having warned witnesses and jurors that they must reveal nothing whatever in public, judges now saw chatty accounts of those same trials in the newspapers. Attempts by the Attorney General to soothe the Lord Chief Justice, Lord Caldecote, and explain the need both to hold the trials in camera, and to secure the co-operation of the press, were not initially successful. Lord Caldecote regarded the statements that had been issued as amounting to contempt of court. By 15 December 1941 peace was restored. It was settled that in future the procedure would include securing the permission of the trial judge and, if there had been an appeal, the Court of Criminal Appeal. This involvement of the judges was, however, to be a mere formality; they would not be shown the statement that was to be issued, which was not based upon what had gone on in the courts. There is no evidence that they pressed for any undertaking to release details of trials in camera after some decent interval, much less for public information that a trial was to take place or had taken place, to be issued before the individual was dead.

The available file ${ }^{144}$ contains the statements released in the cases of Duncan A. C. Scott-Ford (3 November 1942), Johannes M. Dronkers (31 December 1942), ${ }^{145}$ and the original draft of that for Oswald J. Job (executed 16 March 1944). ${ }^{146}$ The form of these statements followed that in Richter's case. That for Scott-Ford says that he 'volunteered' a statement admitting his guilt; he was, at the request of Helenus ('Buster') Milmo, subjected to the rigorous methods of interrogation employed in Latchmere House. ${ }^{147}$ In one case, however, there was no statement; this was the case of Rogerio de Magalhaes Peixto de Menezes, 
an employee at the Portuguese Embassy. ${ }^{148}$ He was arrested and lodged in Latchmere House on 22 February 1943, ${ }^{149}$ and sentenced to death in April 1943 under the Treachery Act. His appeal was dismissed on 13 May, all the proceedings taking place in camera. The judge had given the jury an assurance that a press statement would be made. A Cabinet decision, not recorded in the normal minutes, was made on 27 May approving his reprieve and commuting his sentence to life imprisonment in return for co-operation from the Portuguese government in clearing up a German spy ring in Lisbon. ${ }^{150}$ The Home Secretary, Herbert Morison, thought that a statement would have to reveal why the sentence had been commuted, which was impossible without revealing 'matter which it was in the public interest should be kept secret'. Therefore, 'notwithstanding the obvious objection to not publishing the results of trials held in secret, he was against making any public statement'.

The Cabinet agreed, comforting itself that a mere life sentence was involved, and a public statement might be made at some later date. So far as I am aware this was not done officially until 1990, though information must have been leaked to Allason for his MI5 (1981). ${ }^{151}$ The reply to a Parliamentary question on 18 October 1945 revealed that Menezes had been tried and sentenced to death, but did not reveal that he had not been executed. ${ }^{152}$ Presumably the trial judge and judges of the Court of Criminal Appeal were squared at the time, but the file, much of which has been destroyed, has nothing on this. ${ }^{153}$ Presumably at some point he was deported to Portugal.

A number of less serious OSA and DRS violations were tried in camera during the war; even magistrates were able to exclude the public from hearings of summary offences. Thus George Wace Wall, a radio engineer engaged on secret experimental work, was publicly sentenced to six years after a trial in camera for improper recording of information under the OSA in September $1940 .{ }^{154}$ In July of that year, an engineer who had been working on airfield construction chatted incautiously with a canon of the Church of England, who could have been a spy in disguise; the canon reported him and his case was heard by magistrates partly in camera. He went to prison for three months. ${ }^{155}$ Fusilier Michael Hopper collected information with a view to writing a book after the war; his court martial was held partly in camera. ${ }^{156}$ But many cases were tried in open court for offences of one kind or another against the OSA or DRS, as when a typist in the naval intelligence section of the admiralty took some documents home with no sinister purpose; she went to prison for a month. ${ }^{157}$ The more ridiculous cases mainly occurred in 1940 and 1941.

With the end of the war the emergency legislation went, and the explicit power to hear cases in camera returned to substantially what it had been in the interwar years. One legacy of the war, however, was the extended doctrine of Crown privilege established in the case of Duncan v. Cammell Laird. ${ }^{158}$ This was a suit for damages arising out of the loss of the submarine Thetis, which sank during trials with considerable civilian loss of life. The admiralty wanted 
the hearing to be in camera by judge alone to preserve the secrecy of some of the features of the submarine, but the plaintiff's lawyers were not prepared to consent to this. In the event the case was heard in open court, but the Crown refused to make available numerous documents which contained sensitive information. The House of Lords upheld the Crown's power to withhold documents in litigation, essentially at its discretion. Had the case been tried in camera the issue would never have arisen.

Although quite a number of documents connected with trials in camera are now available in the Public Record Office there is no policy of always releasing papers, including transcripts, under the thirty-years rule, much less a policy of early release. Nor, so far as I know, is there any policy of not destroying records of such trials. The tendency has been for departments, which operate either under rules which are not made public, or under no rules at all, to place relevant files under extended closure, or simply retain them. And under the banner of 'national security' numerous trials in camera have taken place since the Second World War; the ratification and recent incorporation of the European Convention on Human Rights has not affected the practice. ${ }^{159}$ In general the judiciary appear to be perfectly comfortable with this aspect of the secret state, as with others. In participating in secret trials they have, perforce, joined it, in dereliction of their fundamental duty to respect and further the rule of law.

\section{Notes}

This is an expanded version of the Atkin Memorial Lecture originally delivered at the Reform Club on 19 May 1994, which happens to be the day of St Ivo of Kermartin, the patron saint of lawyers. Since writing this I have come across Leonard Sellers's Shot in the Tower (London: Leo Cooper, 1997), which deals with a number of the trials discussed by me. Sellers provides interesting further information about the individuals concerned, but does not address the issue of holding trials in camera.

1 Hansard, Commons Debs, 5th ser., vol. 639, col. 1618 (4 May 1961).

2 See M. Randle and P. Pottle, The Blake Escape (London: Harrap, 1989); and G. Blake, No Other Choice (London: Jonathan Cape, 1990), chs 9 and 10.

3 See R. M. Thomas, Espionage and Secrecy: the Official Secrets Acts 1911-1989 (London: Routledge, 1991), pp. 193-6.

4 E. W. Ives, Anne Boleyn (Oxford: Basil Blackwell, 1986), p. 386.

5 Cobbett's Complete Collection of State Trials, 10 vols (London: R. Bagshaw), vol. 1, p. 1032.

6 Ibid., p. 407.

7 See, for example, C. Cottu, 'On the administration of the criminal code in England and Wales and the spirit of English government', Pamphleteer, 16: 31 (1820), 21, 51.

8 I am indebted for the example and for the passage quoted to David J. A. Cairns, Advocacy and the Making of the Adversarial Trial 1800-1865 (Oxford: Clarendon Press, 1998), p. 16. 
9 R. McGower, 'Civilizing punishment: the end of public executions in England', Journal of British Studies, 33 (1994), 257.

10 W. F. Craies and H. D. Roome (eds), Archibold's Pleading, Evidence \& Practice in Criminal Cases, 24th edn (London: Sweet \& Maxwell, 1910), p. 217 (emphasis added).

118 Edw. VII c. 45 c. 67 (1908).

12 V. Bailey and S. Blackburn, 'The Punishment of Incest Act 1908: a case study of law creation', Criminal Law Review (1979), 708.

1312 \& 13 Geo. V c. 56 (1922), section 5.

14 The Times, (6 June 1925).

15 Ibid., (6 July 1927).

168 Edw. VII c. 67 (1908), sections 114 and 115.

17 [1913] A.C. 417.

18 (1913) L.T.R. 744.

19 (1913) 29 T.L.R. 658.

20 See B. Porter, Plots and Paranoia: a History of Political Espionage in Britain 17901988 (London: Routledge, 1992), esp. chs 5 and 6.

21 See C. Andrew, Her Majesty's Secret Service. The Making of the British Intelligence Community (London: Heinemann, 1985), ch. 2. The critical report is Public Record Office, Richmond (hereafter PRO), CAB 16/8.

$221 \& 2$ Geo. V c. 28 (1911).

23 The Times (16 September1910), PRO, DPP 1/14 (Helm); The Times (29, 30 August. 1911), PRO, FO 371/1126 file 32404 (Schultz); The Times (10 February1912), PRO, DPP 1/16 (Grosse, alias Captain Grant); The Times (23, 24 July 1912) (Graves, or Arngaard Karl); The Times (17 January 1913), R. v. Parrott (1913) 8 CAR 186, PRO, DPP 4/48 and 1/20 (Parrott; the case against Hentschel was dropped); Hampshire Assizes 7, 14, 21 March 1913 (Klauer, alias William Clare); PRO, DPP 1/28, PRO, CRIM 1/45/2 (Schroeder, alias Gould, charged with his wife). See also Andrew, Her Majesty's Secret Service, pp. 61-2, 64-5, 67-9.

24 There are some books of importance on spy cases. Basil Thomson, who was head of the CID and Special Branch, gave accounts based on firsthand knowledge, notably Queer People (London: Hodder \& Stoughton, 1922), and The Scene Changes (London: Collins, 1939). S. T. Felstead, a journalist, wrote an officially approved account, German Spies at Bay (London: Hutchinson, 1922) and edited Steinhauer: the Kaiser's Master Spy (London: Bodley Head, 1930). The corresponding work for later developments is Nigel West [Rupert Allason], MI5: British Security Service Operations 1909-1945 (London: Bodley Head, 1981). J. Bulloch's M.I.5. (London: Arthur Barker Ltd., 1963), is also based on leaked information. On counterespionage especially during the Second World War, see J. Curry, The Security Service 1908-1945 (London: Public Record Office, 1999).

254 \& 5 Geo. V c. 29 (1914), section 1(a).

264 \& 5 Geo. V c. 8.(1914), section 4.

27 DORA, Consolidated Regulations (28 November 1914), section 56.

28 Karl Gustav Ernst was convicted on 11 November 1914 for OSA offences committed before the war. He could not have been tried by court martial for DORA offences, as DORA was not retrospective. His trial was not held in camera. PRO, DPP 1/27; Andrew, Her Majesty's Secret Service, pp. 70-1.

29 Regulation 18A was introduced by Order in Council No. 715 (28 July 1915). 
30 This probably was the case with the spies arrested at the outbreak of the war, listed by Felstead, German Spies, pp. 8-9. Felstead explains the failure to take criminal proceedings by the need to conceal the fact of the arrests, which assumes that they could not have been tried in camera. A later example is Lionel Max Preiznitser (Thomson, Queer People, pp. 159-60, name a pseudonym). Felstead, p. 111, suggests that numerous agents had to be interned for lack of proof.

31 For example, Conrad Leyter was interned in 1915; see Thomson, Queer People, p. 133, Felstead, German Spies, pp. 85-7. The cases of Meta Brunner and Hilda Howsin may be similar; see Felstead, p. 197; Thomson, The Scene Changes, pp. 266-8, 270-2, 278.

324 \& 5 Geo. V c. 29 and c. 63 (1914).

33 Andrew, Her Majesty's Secret Service, 182-4; Bulloch, M.I.5., p. 95; Felstead, German Spies, pp. 23-33, Thomson, Queer People, pp. 122-5. See PRO, DPP 1/29 (transcript); PRO, WO 71/1236, 141/82. See also WO 32/4588, which includes Haldane's minute. G. Oram, Death Sentences Passed by Military Courts of the British Army 1914-24 (London: Francis Boutle, 1998), has Lody tried under DORA, but this is a mistake.

34 G. A. R. Fitzgerald (ed.), Manual of Military Law, 3rd edn (London: H.M.S.O., 1894), para. 41 .

35 Under the International Convention Concerning the Laws and Customs of War on Land, signed 18 October 1907 and ratified by the UK 27 November 1909.

36 H. Godley (ed.), Manual (1914), para. 167.

37 Ibid., para. 445.

38 PRO, WO 105/Gen. No./1829.

39 PRO, WO 32/4588, memorandum of 13 August 1914.

40 PRO, WO 32/4588 minute by the Advocate General.

41 At this time junior treasury counsel and senior counsel at the central criminal court, later director of public prosecutions.

42 See Thomson, The Scene Changes, pp. 249-51; Queer People, pp. 122-6; and Felstead (ed.), Steinhauer, p. 45.

43 Felstead (ed.), Steinhauer, p. 38; Burkard Baron von Müllenheim-Rechberg, Battleship Bismarck: a Survivor's Story, trans. Jack Sweetman (London: Arms \& Armour Press, 1991), pp. 83, 101.

44 See H. Lauterpacht (ed.), Manual (1958), pp.106 and 108.

45 See PRO, WO 215/12. WO 32/4898 has a list of 'Spies tried by military courts' abroad. There are forty-nine names, the trials taking place at Alexandria (1), Douglas (1) H.Q. 10th Division (1), Ahmednagar (14), Kiraissi in Macedonia (12), in the field (1), Salonika (9), Port Sudan (6), Malta (4). Of these persons nine appear to have been executed. Oram, Death Sentences, has one Egyptian hanged under martial law in what may have been an espionage case. He also has, at p. 39, one M. S. Hussein acquitted of war treason; this is a mistake as Hussein was executed.

464 \& 5 Geo. V c. 8 (1914).

4744 \& 45 Vict. c. 58 (1881).

48 Godley (ed.), Manual (1914), ch. 5, para. 71.

49 PRO, WO 32/4898 with reference to folio 17/1. This has a complete list.

50 In what follows I have used Oram's valuable Death Sentences, but my account differs in some respects, and is based on a more extensive archival basis. Oram does not, of course, deal with civil trials. 
515 Geo. V c. 34 (1915).

52 See PRO, WO 32/5526.

53 PRO, WO 32/3989 and 3990; practice changed by Army Council Instruction 570 of 22 March 1918.

54 Oram, Death Sentences, p. 15.

55 PRO, DPP 1/41, case of Robert Rosenthal. He had falsely claimed American citizenship, and was tried by court martial.

56 PRO, WO 32/4588 and 4898.

57 The four were Rikard Leopold Vieyra (14 December 1916, Dutch); G. V. Bacon (26 February 1917, American); A. Hagn (27 August 1917, Norwegian); L. Goten (24 September 1917, Belgian). Dates give the start of each trial.

58 C. H. Lody (30 October 1914, German); H. M. P. Janssen (16 July 1915, Dutch); W. R. Roos (16 July 1915, Dutch); E. W. Melin (28 October 1915, Swede); A. A. Roggen (20 August 1915, Uruguayan); F. Buschmann (28 September 1915, Brazilian); I. G. Ries (4-5 November 1915, American); A. Meyer (5 November 1915, Danish, on whom see PRO, WO 141/83); L. H. J. Zender (20 March 1916, Peruvian).

59 R. Rosenthal (11 July 1915, German).

60 PRO, WO 32/4898 also lists ten spies tried by court martial and thirty-nine by military tribunals abroad of whom seven were executed. I have not investigated whether these trials took place in camera.

61 Alias Copperlee. For accounts, see Thomson, Queer People, pp. 126-9; Felstead, German Spies, pp. 33-40; PRO, WO 141/1/3, CRIM 1/153/3, HO 144/1429/ 288639. The Times (19, 20, 21 May 1915).

62 PRO, DPP 1/38, CRIM 1/683, 684, 685, WO 141/2/2; The Times (28 May, 21 April, 5 June, 22 June, 24 June 1915); Felstead, German Spies, pp. 44-52; Thomson, Queer People, pp. 130-3.

63 Reported as R. v. M., 32 T.L.R. 1 (1915).

64 PRO, DPP 1/41, WO 32/4898, 141/1/5, HO 144/288639; Felstead, German Spies, pp. 54-7; Thomson, Queer People, p. 148.

65 See PRO, WO 32/4588.

66 Felstead, German Spies, p. 56.

67 PRO, DPP 1/33, WO 71/1312, 92/3, 32/4898; Thomson, Queer People, pp. 1357; Felstead, German Spies, pp. 102-9; The Times (15 July 1915).

68 Thomson, Queer People, p. 137; Felstead, German Spies, p. 109; J. Bulloch, M.I.5., pp. 116-21. Bulloch indicates they were Janssen, Roos, Wertheim, Breeckow, Buschmann, and Guerrero. However Felstead, p. 110, indicates that Buschman was not one, and Oram, Death Sentences, has Buschman executed on 19 October 1915, relying on PRO, WO 92/3 and 71/1313. His text suggests that Auguste Alfredo Roggen, a Uruguayan, executed 18 September 1915 was, and that another suspect was deported. This may be Raymonde Amondarin, Guerrero's girl friend, against whom charges were dropped.

69 For example, the case of Ernst Gustav Waldemann Olson. The Times (13 July 1915); PRO, DPP 1/37, 4/49.

70 PRO, DPP 1/35, WO 71/1237, 141/2/3, 92/3; Felstead, German Spies, p. 134; Thomson, Queer People, p. 146.

71 PRO, DPP 1/40, WO 141/61, 92/3; Thomson, Queer People, pp. 144-6; Felstead, German Spies, p. 125. 
72 PRO, DPP 1/31. Thomson, Queer People, p. 141, has him tried at the Westminster Guildhall on 20 September but this is incorrect. See also PRO, WO 92/3, 71/ 1313.

73 Thomson, Queer People, pp. 141-3.

74 PRO, DPP 1/34, WO 32/4898; Thomson, Queer People, pp. 171-3; Felstead, German Spies, pp. 181-2.

75 One file in the Public Record Office, CRIM 1/683, contains a wizened lemon whose juice was, presumably, employed as ink.

76 Thomson, The Scene Changes, p. 357; Felstead, German Spies, p. 52.

77 The Times (21, 28 May, 1, 5, 19, 22, 24 June 1915). Curry, Security Service, p. 76, states that in one case a German agent was impersonated after his execution, but does not provide a name.

78 PRO, DPP 1/42, WO 32/4898; Thomson, Queer People, pp. 157-9, The Times (26 October 1915); Felstead, German Spies, pp. 152-6.

79 Felstead, German Spies, p. 155.

80 Thomson, Queer People, pp. 187-90; Felstead, German Spies, pp. 187-96; PRO, DPP 1/32 (case papers), 4/51 and 52 (transcripts), PCOM 8/245 (with photo), WO 32/4898 (release and list of spies still in prison after the armistice).

81 Lauterpacht (ed.), Manual (1958), part 3, p. 183, states that Edith Cavell was convicted of what might be called war treason - aiding prisoners to escape.

82 The Times (13 January, 18 February 1916).

83 PRO, DPP $1 / 32$.

84 See PRO, WO 32/4898.

85 (1916) 85 L.J.K.B. 857, 32 T.L.R. 303 (Divisional Court) and 369 (Court of Appeal). Andrew, Her Majesty's Secret Service, pp. 192-3; and F. L. Carsten, War Against War (London: Batsford, 1982), pp. 55-6, are referring to a different incident.

86 DORA, Regulation 51A (28 July 1915).

87 See ex parte Norman (1916) 114 L.T.R. 232, and K. D. Ewing and C. A. Gearty, The Struggle for Civil Liberties. Political Freedom and the Rule of Law in Britain, 1914-1945 (Oxford: Clarendon Press, 2000), pp. 65-8.

88 (1916) 85 L.J.K.B. $857,859$.

89 Ibid., pp. 860-1.

90 Ibid., p. 861.

91 [1917] 2 K.B. 254, more fully reported at (1917) 33 T.L.R. 222. See Ewing and Gearty, Civil Liberties, pp. 343-5.

92 Godley (ed.), Manual (1939), ch. 3, para. 37. ch. 8, para. 41, n. 5 mentions a case in Calcutta (Ricketts v. Walker, 1841) where a reporter whose notes were seized after he had been ordered not to take notes was awarded nominal damages. The case is reported in W. Hough, Precedents in Military Law (London: W. H. Allen \& Co., 1855), p. 718.

93 All courts martial held in connection with the Easter Rising were in camera, and since this chapter was written some material dealing with their legality has been released in the PRO, which I have not had an opportunity to consult. See in particular WO 141/21 (shooting of civilians by troops in 1916) and WO 141/27 (supply of copies of courts martial proceedings).

94 The institution which handled counter espionage work in Britain during the First World War was called MO5g until January 1916, when it was renamed MI5. 
This formed part of MO5, the institution being referred to, rather than the Directorate of Intelligence within the Home Office established in 1919 and run by Thomson. There was also within GHQ a unit concerned with obtaining intelligence related to revolutionary movements and industrial unrest in Britain, set up in 1919. Thereafter the army wanted wished to have no connection with domestic secret intelligence, and this unit went early in 1920, but in response to pressure from Lloyd George and Winston Churchill a small liaison unit continued, called M04x, but this was disbanded in 1922. See PRO, WO 32/5553, 106/45/525; Andrew, Her Majesty's Secret Service, pp. 343-4.

95 See PRO, WO 32/13733.

96 PRO, WO 32/4896.

97 See PRO, CAB 24/109 (CP No. 1604 of 1920. Review of the Defence Regulations, paper circulated by Churchill 12 July 1920). The report of the Cave Committee is PRO, GT 6350 and should be in CAB/70.

98 PRO, PRO 32/13733.

$9910 \& 11$ Geo. 5 c. 75 (1920).

100 The history of OSA 1911 and 1920 is discussed in D. Williams, Not in the Public Interest (London: Hutchinson, 1965), ch. 1; Thomas, Espionage and Secrecy, ch. 1; and D. Hooper, Official Secrets: the Uses and Abuses of the Act (Sevenoaks: Coronet, 1988), ch. 2.

101 See Williams, Public Interest, p. 33; PRO, DPP 1/25.

102 The Times, (16 November, 8 and 16 December 1926); PRO, HO 144/1982; Williams, Public Interest, p. 63; PRO, CRIM 1/380; Hooper, Official Secrets, pp. 38-40. Another case two years later involved Archibald Taylor, a junior civil servant engaged in corruption. See Hooper, Official Secrets, p. 40.

103 Hooper, Official Secrets, p. 32.

104 Goertz was convicted on 9 March and sentenced to four years' imprisonment. See The Times (5, 6, 7, 10 March 1936). See also PRO, CRIM 1/813.

105 The Times (25 September 1936).

106 See West, MI5, p. 81; A. Masters, The Man Who Was M: the Life of Maxwell Knight (Oxford: Basil Blackwell, 1984), ch. 4; The Times (4, 8, 12 February 1938). Williams, Public Interest, p. 104, notes that in the five years up to May 1938 the Attorney General had consented to OSA prosecutions in twenty-eight cases, and refused consent in ten. Hooper, Official Secrets Appendix I, lists three of these cases. For the period between 1920 and 1939 he lists seven cases: Michael Simington (June 1920, PRO, DPP 4/54); Lionel Ballard Frederick Budgen (June 1932); William Burger (January 1935); Albert Fulton (March 1935); James Goodrich and Sidney Norris (September 1937); Wilfred Vernon (October 1937); Edward Edwards (May 1939); Walter Moore (May 1939). He notes that Moore's trial was largely in camera. Probably so was that of Burger, who was connected with the Woolwich Arsenal case.

107 Case of Eric J. C. Camp, see The Times (27 October 1936).

108 See PRO, AIR 2/17425. Donelly's Air Ministry file was number 893013/28, but it is not available. I have also relied on AIR 2/718 and WO 141/60 (formerly PRO, WO 32/60). The case does not seem to have attracted the attention of the press.

109 The trial resulted from a raid on the Russian trade delegation in London on 12 14 May 1927. The only file listed in the PRO, CRIM 1/418, was not available 
when I last ordered it. Accounts of the case are given in West, MI5, pp. 62-75; and Andrew, Her Majesty's Secret Service, pp. 467-73.

110 The reference is to his minute on 893013/28. See note 107 above.

111 PRO, KV 2/174-192, WO 71/1033, 209/114; West, MI5, pp. 100-10; The Times (21-5, 28-9 March 1933) (coverage of the trial itself). Under section 41 of the Army Act, if the accused was a serving officer, he could be tried by court martial.

112 PRO, WO 141/60 (formerly WO 32/60), law officers' opinion, 1 March 1933.

113 Ibid., letter by Sir Alexander Maxwell, 23 June 1936.

114 Ibid. (Scottish Office memorandum).

115 Ibid. (law officers' opinion).

1163 \& 4 Eliz. II c. 18 (1955), section 94 (2).

117 See A. W. B. Simpson, In the Highest Degree Odious (Oxford: Oxford University Press, 1994), ch. 3.

1182 \& 3 Geo. VI c. 62 (1939), section 6. The provision of OSA was suspended.

119 PRO, WO 32/4588. The Home Office took the same line over the arrangements for an invasion in 1940-1. See Simpson, Highest Degree, pp. 190-2.

120 PRO, WO 32/4588, including a letter from Maxwell to Sir James Grigg, 31 October 1939.

121 PRO, HPC (39) 86.

122 PRO, WO 32/4588, memorandum by H. D. F. MacGeagh, Judge Advocate General, 24 November 1940.

123 See PRO, HPC (40) 66, memorandum by the home secretary, 15 March 1940; HPC (40) 105, 4 May 1940.

124 PRO, FO 371/5084, prepared for a parliamentary question of 18 October 1945 in Hansard, Commons Debs, 5th ser., vol. 414, col. 1513. F. H. Hinsley and C. A. G. Simkins, British Intelligence in the Second World War, 5 vols, (London: H.M.S.O., 1990), vol. 4, pp. 92, 97 n. (discussing press releases). PRO, HO 45/25595 has a note on the aftermath. See also West, MI5, pp. 324-8.

125 O. Hoare (ed.), Camp O20: MI5 and the Nazi Spies (Richmond: Public Record Office, 2000), p. 156. See PRO, WO 32/18144.

126 The story originated with one John McGowan, who was at the time a staff officer with fighter command; see Luton Herald (10 June 1979). The supposed executions do not feature in a list of death sentences carried out in PRO, WO 93/40.

127 See J. Douglas-Hamilton, Motive for a Mission (London: Macmillan, 1971), p. 197; J. Leasor, Rudolf Hess, The Uninvited Envoy (London: Allen \& Unwin, 1962), pp. 149-50; L. Picknett, O. Prince, and S. Prior, Double Standards: the Rudolf Hess Cover-up (London: Little Brown, 2001), p. 309; P. Padfield, Hess: Flight for the Fuehrer (London: Weidenfeld \& Nicolson, 1991), pp. 251-2.

128 Lauterpacht (ed.), Manual, (1958), pt 3, p. 108 (emphasis added).

129 West, MI5, p. 90; Cadogan Diary (Archives of Churchill College Cambridge as ACAD) September 1939; PRO, CRIM 1/1129, TS 27/1217; W. Cameron Watt, 'Francis Herbert King: a Soviet source in the Foreign Office', Intelligence and National Security, 3 (1988), 62-82; G. Brook-Shepherd, The Storm Petrels: the First Soviet Defectors, 1928-1938 (London: Collins, 1977), pp. 172-80; Curry, Security Service, pp. 189-90.

130 Harvey had been appointed a cypher officer in 1919; he was still employed by the Foreign Office in 1940, and must have been exonerated. 
131 Russell, Kinnaird, Maling, and Tubb were all apparently exonerated. Russell received an MBE in 1939.

132 G. Brook-Shepherd, Storm Petrels, p. 176, has it that King's controller was Theodore Maly, who was also known as Paul Hardt.

133 West's account, MI5, pp. 73-4, does not tally with the case papers, which indicate that in his first statement King did not confess. See PRO, CRIM 1/1129 and TS $27 / 1217$.

134 The Times (8 June 1956).

135 PRO, FO 371/5084 (prepared for a Parliamentary question on 18 October 1945).

136 Hansard, Commons Debs, 5th ser., vol. 414, col. 1513 (18 October 1945). See PRO, CRIM 1/1449, HO 45/25763, KV 2/57-59. The others were Karl Theo Drueke (Drüke) and Francis Johannes Winter.

137 See Simpson, Highest Degree, pp. 154, 156, 241, 392.

138 See The Times (18 December 1940) and (11 February 1941).

139 PRO, HO 45/25741.

140 All material on press releases is taken from PRO, HO 45/25595. PRO, PCOM 9/ 2121 contains an example of the grim form returned to the Home Office after an execution had been carried out, which, for example, reported on the conduct of the executioners.

141 PRO, HO 144/21471-2.

142 Star (16 August 1941); Evening Standard (16 August 1941).

143 PRO, CRIM 1/1350, KV 2/30-33.

144 PRO, HO 45/25595.

145 See also PRO, CRIM 1/1454, HO 45/25603, KV 2/43-46.

146 See also PRO, HO 144/22028.

147 See PRO, HO 45/25763. There is an account by R. W. G. Stephens in Hoare (ed.), Camp 020, pp. 195-8, which maintains, however, that Scott-Ford willingly co-operated.

148 See Hoare (ed.), Camp 020, pp. 47-8, 237-9.

149 See PRO, HO 45/25111, which has lists of those in MI5's private prisons, Latchmere House (Camp 020) and Huntercombe Place (Camp 020R).

150 PRO, WM (43) 78th.

151 Accounts are in Hinsley and Simkins, British Intelligence, vol. 4, pp. 110-12, 186, 204; and in West, MI5, pp. 345-6.

152 Hansard, Commons Debs, 5th ser., vol. 414, col. 1513 (18 October 1945).

153 Judges known to have presided over the trial of spies during the war were Hilbery (King); Tucker (Kent, Wolkoff, Richter); Wrottesley (Waldberg, Kieboom, Meier, Pons, Dronkers); Lewis (Armstrong); Asquith (Waelti and Druecke); Humphreys (Key, Timmerman, Winter); Birkett (Scott-Ford); Stable (Job); Hallett (Vanhove).

154 The Times (19 September 1940); PRO, CRIM 1/1223.

155 Case of Harvey Blessington Young, The Times (17 July 1940).

156 The Times (2 September 1940).

157 Case of Ethel E. Mann, The Times (5 July 1940).

158 [1942] A.C. 642. See PRO, TS 32/101-17.

159 See A. W. B. Simpson, Human Rights and the End of Empire: Britain and the Genesis of the European Convention (Oxford: Oxford University Press, 2001), pp. 399, 465$6,694,732,1061$. 